\title{
Instrumenting Wildlife Water Developments to Collect Hydrometeorological Data in Remote Western U.S. Catchments
}

\author{
Nicholas Grant,,${ }^{,+}$Laurel Saito, ${ }^{\#}$ MARK Weltz,${ }^{@}$ MARK Walker, ${ }^{\&}$ Christopher Daly, ${ }^{* *}$ \\ KELLEY STEWART, ${ }^{\&}$ AND CHRISTO MORRIS ${ }^{@}$ \\ * Graduate Program of Hydrologic Sciences, University of Nevada at Reno, Reno, Nevada \\ \# Department of Natural Resources and Environmental Science, and Graduate Program of Hydrologic Sciences, \\ University of Nevada at Reno, Reno, Nevada \\ @ Agricultural Research Service, U.S. Department of Agriculture, Reno, Nevada \\ \& Department of Natural Resources and Environmental Science, University of Nevada at Reno, Reno, Nevada \\ ** PRISM Climate Group, Northwest Alliance for Computational Science and Engineering, School of Chemical, \\ Biological, and Environmental Engineering, Oregon State University, Corvallis, Oregon
}

(Manuscript received 27 March 2012, in final form 21 January 2013)

\begin{abstract}
In the arid western United States, wildlife water developments, or "guzzlers," are important water sources for wildlife, and consist of impermeable roof structures designed to intercept precipitation and small tanks for storing water. Guzzlers are typically installed in remote mid- to high-elevation basins, where precipitation data are often scarce. In this study, small-game guzzlers were examined for feasibility as potential sites for improving estimates of climatic parameters in remote Nevada catchments. Instruments measuring liquid precipitation and water level were installed at two guzzler field sites. Although one field site was vandalized during the study, field results indicated that water levels in the tank measured by Hobo pressure transducers corresponded well with precipitation events measured by the Texas Electronics tipping-bucket rain gauge, and that measured data were similar to Parameter-Elevation Regressions on Independent Slopes Model (PRISM) estimates. Minimum temperatures from the guzzler sites were similar to PRISM; however, maximum temperatures were a few degrees higher, possibly because temperature sensors were unshielded. With over 1600 guzzlers in Nevada and thousands more throughout the western United States, this study initiates exploration of the feasibility of augmenting individual guzzler sites to enhance climatic monitoring at a relatively low cost to improve the quality and density of climate observations, benefitting hydrologists, climatologists, and wildlife managers.
\end{abstract}

\section{Introduction}

Guzzlers are artificial catchments designed to collect and store precipitation, making water available to wildlife throughout the year, with thousands located throughout the western United States. Guzzlers can be constructed for small or large game, and their importance as a water source for wildlife has been well

\footnotetext{
+ Current affiliation: Hubbard Brook Experimental Forest, North Woodstock, New Hampshire.

Corresponding author address: Laurel Saito, Associate Professor, Department of Natural Resources and Environmental Science, and Director, Graduate Program of Hydrologic Sciences, University of Nevada at Reno, Mail Stop 186, Reno, NV 89557. E-mail: 1saito@cabnr.unr.edu
}

documented (Rosenstock et al. 1999; Bleich et al. 2006; Dolan 2006; O'Brien et al. 2006; Lynn et al. 2006, 2008). This study focuses on small-game guzzlers (Fig. 1), which typically consist of an impermeable roof structure designed to intercept precipitation, approximately $0.6-$ $0.9 \mathrm{~m}(2-3 \mathrm{ft})$ off the ground and slightly sloped to encourage runoff to flow into a gutter on the downslope side. Water flows from the guzzler roof structure into a partially buried cistern [ $\sim 1200-\mathrm{L}$ (325 gal) capacity] that is open on one end to allow access to wildlife. The structure is surrounded by a barbed wire fence to prevent guzzler access by cattle, wild horses, and burros. Guzzlers are constructed with relatively low-cost materials. Thousands of guzzlers exist throughout the western United States, including over 1600 in the state of Nevada (Fig. 2). Guzzlers are typically installed in remote mid- to high-elevation basins by the Nevada 


\section{Nevada Department of Wildlife 1230 Liter Guzzler Design}

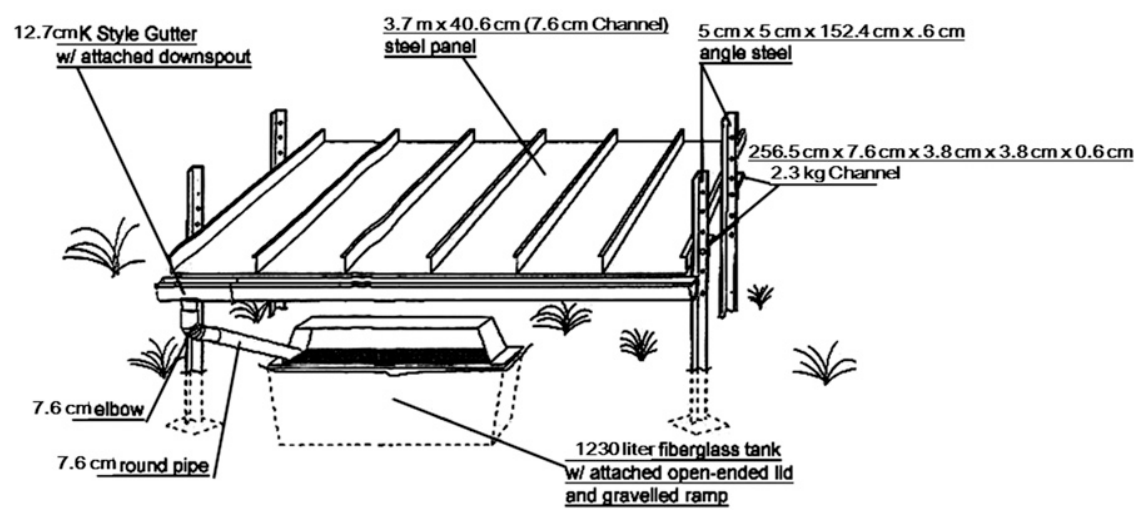

FIG. 1. Schematic of small-game wildlife water development "guzzler" (modified from NDOW).

Department of Wildlife (NDOW) or volunteer conservation groups, and these organizations visit and/or maintain most guzzlers approximately once per year.

In this study, small-game guzzlers were examined for feasibility as potential sites for data collection to improve estimates of climatic parameters in remote Nevada catchments. Precipitation gauge density in the state of Nevada is the lowest in the contiguous United States (Dingman 2002). Because of this poor gauge coverage, precipitation and runoff must be estimated for most areas with hydrologic models using limited data. This lack of available observations becomes a problem when modeling precipitation over complex, often mountainous terrain typical in Nevada (Daly et al. 1994, 2008). Models such as the Parameter-Elevation Regressions on Independent Slopes Model (PRISM) produce high-resolution, spatially complete estimates of climatological elements for the entire state, but reliability of these estimates depends on the quality and coverage of precipitation measurements (Daly 2006).

Most of the publically available observed precipitation data in Nevada come from the National Weather Service (NWS) Cooperative Observer (COOP) network, which includes 178 current and historic sites in Nevada (WRCC 2011). Most of these COOP network voluntary observers live in populated areas, leaving many remote areas of the state unmonitored (Fig. 2). To model precipitation in mountainous environments, it is best to have point observations that cover a range of elevations and orographic positions (Bales et al. 2006).

Furthermore, despite training by the NWS and access to a handbook describing procedures for collecting data, observational biases are common throughout the COOP network (Daly et al. 2007). The standard NWS 8-in.
$(0.2 \mathrm{~m})$ nonrecording precipitation gauge employed at COOP network sites also has systematic errors associated with wind and evaporation (Yang et al. 1998), although some COOP sites also use Fischer \& Porter or Belfort Universal gauges. One solution to observer bias would be to automate the system (Daly et al. 2007; Fiebrich and Crawford 2009), eliminating the need for manual measurements, while also increasing the frequency at which measurements are collected.

In addition to data from COOP network sites, climate data are publicly available from nine fully automated Soil Climate Analysis Network (SCAN) sites and 31 Snowpack Telemetry (SNOTEL) sites operated by the Natural Resources Conservation Service (NRCS) in the state of Nevada. A standard SCAN site collects precipitation, air temperature, relative humidity, wind speed, wind direction, solar radiation, barometric pressure, snow water content, snow depth, soil moisture, and soil temperature data (NRCS 2009b). SNOTEL sites typically include a snow pillow, snow depth sonic sensor, air temperature sensor, and storage precipitation gauge. Some sites also include instruments to measure barometric pressure, relative humidity, soil moisture, soil temperature, solar radiation, wind speed, and wind direction (NRCS 2009a). Both SCAN and SNOTEL sites in Nevada are typically installed at high elevations.

Another source of automated precipitation measurements in Nevada is the Remote Automatic Weather Stations (RAWS), with 91 current and historic sites throughout the state. The RAWS network collects precipitation data via a tipping-bucket rain gauge. Point observations of precipitation are also available from the Community Collaborative Rain, Hail and Snow Network (CoCoRaHS), a network of volunteer-run sites 


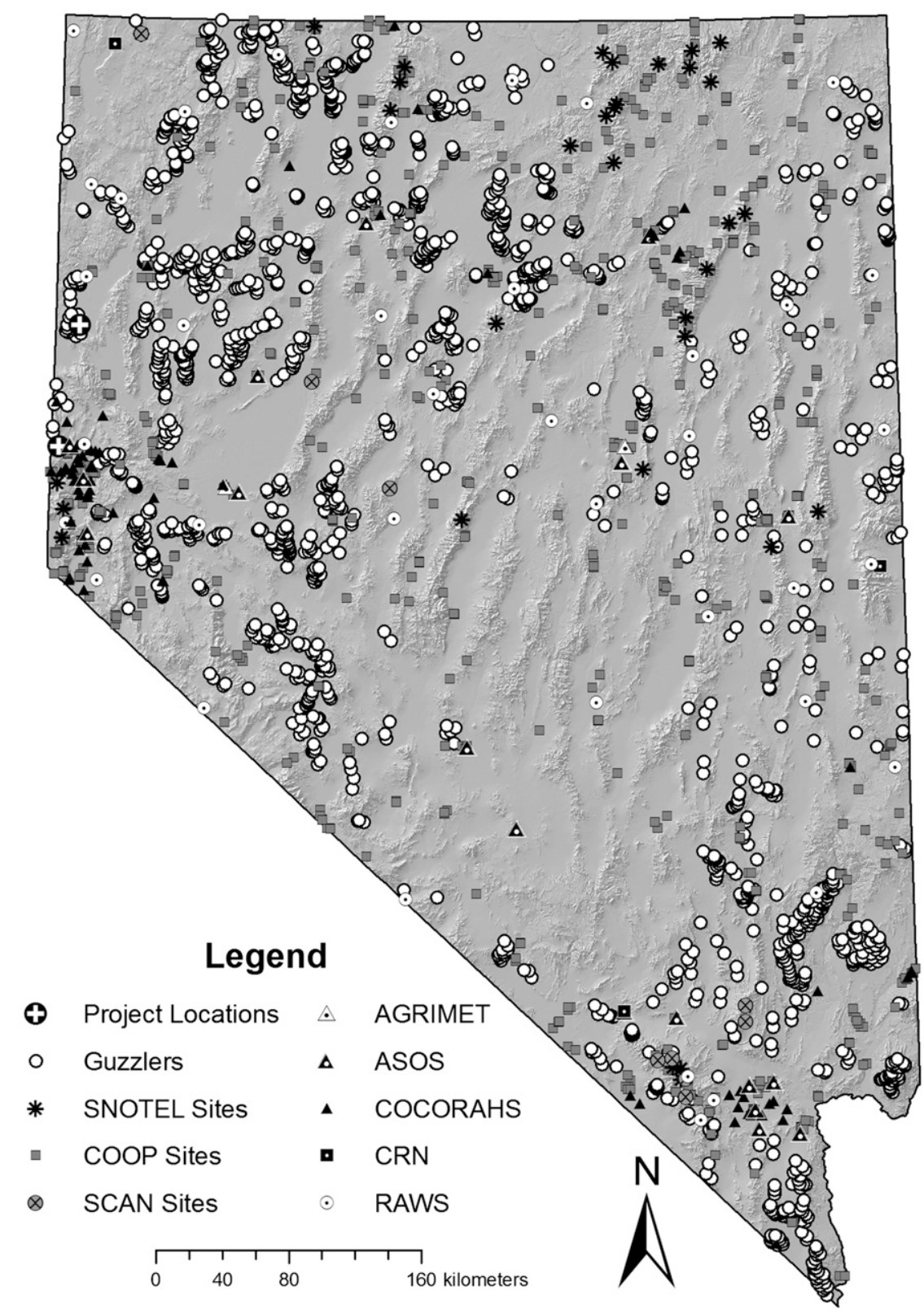

FIG. 2. Map showing the locations of the two guzzler field sites and other climate monitoring sites in Nevada. AGRIMET = Pacific Northwest Cooperative Agricultural Weather Network; ASOS = Automated Surface Observing System; AWOS = Automated Weather Observing System; CoCoRaHS = Community Collaborative Rain, Hail and Snow Network; COOP = Cooperative Observer Network; CRN = Climate Reference Network; RAWS = Remote Automatic Weather Station network; SCAN = Soil Climate Analysis Network; SNOTEL = Snow Telemetry.

similar to the COOP network in method and scale. There are 235 CoCoRaHS sites in Nevada, most of which are located near population centers, frequently at lower elevations. Quantitative precipitation estimation (QPE) radar estimates are also available, but are of poor quality over most of Nevada because of terrain blockage and a general lack of radar coverage. There are $15 \mathrm{Au}-$ tomated Surface Observing System (ASOS)/Automated Weather Observing System (AWOS) sites that monitor weather conditions at airports in Nevada in populated areas. There are also three U.S. Climate Reference Network (CRN) sites in Nevada. However, despite the 
seemingly large number of in situ precipitation stations within Nevada, they exhibit low density relative to the land area of the state, are concentrated near population centers, and leave significant remote and mountainous regions of the state unmonitored (Fig. 2).

Instrumenting guzzlers to collect climatic data could be one way to automate the system of stations in Nevada while dramatically increasing data coverage in remote mid-elevation regions. Several studies of climate trends in the western United States have indicated that midelevation catchments have experienced significant changes in precipitation type (i.e., snow vs rain; Das et al. 2009; Knowles et al. 2006; McCabe et al. 2007), and this trend may continue with climate change, so capturing climate data in this sensitive zone is critical. Using the guzzler's structure, instruments can be mounted easily and remain somewhat protected behind the barbed wire fence that surrounds guzzler sites. A guzzler can be instrumented to collect precipitation, air temperature, water storage, runoff, and wildlife visitation data for less than $\$ 5000$, with installation typically taking only a few hours. Data could be downloaded by NDOW employees or conservation group volunteers who visit the sites on a regular basis for routine maintenance, typically at least once per year. The Western Regional Climate Center (WRCC) is willing to archive the guzzler data and allow access through their online data portal. Therefore, material costs, installation time, and funds required for data retrieval, archival, and access would be much less than for a typical meteorological site, offering an excellent opportunity to improve precipitation gauge coverage in remote areas of Nevada in a cost-effective manner. New sites could be instrumented, new instrument configurations tested, and the spare instrument inventories established and grown as funding allows.

This paper describes a pilot project investigating the feasibility of instrumenting small-game guzzlers to collect climatic data in remote Nevada catchments. If guzzler sites could be reliably instrumented at relatively low cost, then it may be possible for many guzzler sites to be outfitted similarly, significantly augmenting precipitation data in areas that otherwise are underrepresented in current physical networks. Results from this study should provide the organizations responsible for the installation and maintenance of guzzlers with options for effectively outfitting additional guzzlers to collect climatic and runoff data in remote areas.

\section{Methods}

\section{a. Field sites}

Instruments for measuring precipitation and water level were installed at two guzzler field sites that were selected based on proximity to Reno, Nevada; accessibility; visibility; condition of the guzzler structure; and location in the watershed. The first site selected, Dry Valley Rim No. 11, is located in Dry Valley, approximately $18 \mathrm{~km}$ northwest of Pyramid Lake, Nevada (Fig. 2). The site is located in the Smoke Creek Desert watershed. The terrain is composed of gently sloping ridges and hills. Dry Valley Rim No. 11 is about halfway up a hillslope at $1337-\mathrm{m}$ (4386 ft) elevation on land managed by the U.S Bureau of Land Management (BLM).

The second site, Petersen No. 1, is located in the Petersen Range, approximately $19 \mathrm{~km}(11.8 \mathrm{mi})$ northwest of Reno (Fig. 2) and is part of the Honey-Eagle Lakes watershed. The terrain is composed of small rolling hills, and Petersen No. 1 is near the bottom of a small drainage at an elevation of $1619 \mathrm{~m}(5312 \mathrm{ft})$. The surrounding lands are a mix of private and BLM ownership.

\section{b. Instrumentation}

There are challenges and considerations for using guzzlers to collect hydrologic data. Because of the remote location of most wildlife water developments, data retrieval can be difficult. Some traditional methods of remote data retrieval such as radio [very high frequency (VHF)] and satellite are not feasible. Radio retrieval of data requires a direct line of sight between radio towers, as well as a dedicated frequency for communication. Satellite data retrieval can be very expensive. Data retrieval can also be accomplished using cell phone signals, but most guzzler sites receive insufficient or no cell phone service. Therefore, data will need to be stored onsite for downloads that may occur only once per year. Site visitations for maintenance and data retrieval will likely be made by people with nontechnical backgrounds. Because sites will be powered by a solar panel/ $12-\mathrm{V}$ battery system, instruments with large power requirements are not feasible. Thus, pressure transducers and tipping-bucket rain gauges are considered most appropriate for power availability, data storage, and download requirements.

Site instrumentation will be subjected to prolonged exposure to extreme high and low temperatures, desiccation, high winds, and contact with wildlife as well as humans, so instrumentation must be able to perform in adverse conditions. Therefore, ideal instruments for deployment need to be robust, simple to install, easily maintained, and affordable. Tests were performed on potential instruments at the University of Nevada at Reno (UNR) under extreme temperature conditions similar to those that have been observed in Nevada (Grant 2010). While other types of gauges were considered in the selection process, the tipping-bucket gauges were ultimately selected for testing because of 
the relatively low maintenance, power, and cost requirements of these types of gauges. The Texas Electronics (TE) TE525USW (\$385 each, Campbell Scientific, Logan, Utah) with Hobo U11-001 dataloggers (\$125 each, Onset, Bourne, Massachusetts) and the RainWise (RW) tipping-bucket gauge with RainLog datalogger (\$170 each, RainWise, Bar Harbor, Maine) were tested at UNR. Hobo U20-001-04 (\$495 each, Onset, Bourne, Massachusetts) and the Solinst 3001LT Levelogger Junior (\$385 each, Solinst, Georgetown, Ontario, Canada) pressure transducers were also tested under the same extreme temperature conditions. Results indicated that the TE rain gauge performed more reliably than the RW gauge, especially under prolonged freezing conditions when the RW gauge's datalogger tended to malfunction and reset to 1200:00 1 January 2000. Overall, the Solinst pressure transducers were not as affected by prolonged freezing conditions as Hobo pressure transducers as long as the transducers were protected by a saline solution (Grant 2010).

To measure precipitation at the pilot sites, the TE tipping-bucket rain gauge was selected for deployment. Biases common to the design include wind-induced bias and an underestimation of high rainfall intensities (Groisman and Legates 1994; Nystuen et al. 1996; Habib et al. 2008). While most manufacturers will calibrate tipping-bucket gauges, it is typically performed at a low fixed rainfall rate of a few millimeters per hour. However, this method of calibrating the volume of water required for one "tip" of the bucket does not translate well to high intensities, when water can be missed between bucket tips (Habib et al. 2008). This underestimation of precipitation at high storm intensities is a systematic bias. It is possible to adjust the data, and a variety of correction models exist to adjust data collected with a tipping-bucket gauge (Sevruk 1996).

In February 2009, each guzzler was instrumented with a TE525WS tipping-bucket rain gauge, Campbell Scientific CR1000 datalogger with onboard thermistor (\$1390, Campbell Scientific, Logan, Utah), and a 30-W solar panel (\$186, BP Solar, Frederick, Maryland). The CR1000 and battery are housed in a $30.5 \mathrm{~cm} \times 35.6 \mathrm{~cm}$ $(12$ in. $\times 14$ in.) weather resistant enclosure $(\$ 215$, Campbell Scientific, Logan, Utah). Total precipitation and minimum, maximum, and average air temperature were recorded each hour by the datalogger. Battery voltage was also recorded each hour. A HOBO U20001-04 pressure transducer was installed in the guzzler cistern to monitor fluctuations in water storage every $30 \mathrm{~min}$ throughout the year. Another HOBO U20-001-04 pressure transducer was installed on-site for barometric compensation of the water-level data. A motion-sensor wildlife camera ( $\$ 199$, Cuddeback, Green Bay, Wisconsin) was installed on-site to monitor wildlife visitation to the guzzler.

The TE tipping-bucket rain gauge was installed ap-

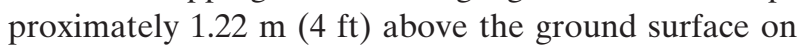
the guzzler frame to make sure it did not obstruct the guzzler roof. The solar panel and enclosure housing the datalogger were similarly installed using the guzzler frame for support (Fig. 3). The wildlife camera was installed on a fence post near the guzzler, oriented toward the tank opening to monitor wildlife visitation.

Water in the cistern is susceptible to freezing during winter months and such freezing can supply sufficient pressure to cause permanent damage to a pressure transducer. Thus, the pressure transducer in the guzzler cistern was installed in a sealed heavy-grade elongated balloon (part 29-4522/10, ELE International, Loveland, Colorado) filled with a saturated salt solution. The solution's freezing point is sufficiently low to act as a buffer between the ice and the pressure transducer. The pressure transducer can still read pressure fluctuations while installed in this manner, and it remains protected when water in the cistern freezes. In addition, the salt solution should minimally impact wildlife should the balloon rupture inside the cistern. For barometric pressure compensation, one Hobo pressure transducer was installed near the datalogger enclosure.

Each guzzler site was visited every few months as weather permitted to verify that instrumentation was functioning properly, to download data, and to relaunch monitoring devices. Data collection at the Petersen No. 1 and Dry Valley No. 11 sites began on 24 February 2009 and 31 January 2009, respectively. Data are still being collected, although sometime between site visits on 5 August 2009 and 22 October 2009, the Petersen No. 1 guzzler instrumentation was vandalized. Precipitation data were not collected at the site after the vandalism occurred until the instrumentation was replaced on 12 May 2010. However, water levels in the cistern indicated that a precipitation event occurred during the period when precipitation data were not collected. Water levels in the cistern were not collected after 1 October 2010 and 17 September 2010 at the Dry Valley No. 11 and Petersen No. 1 guzzlers, respectively, because of human failure to reset the pressure transducers.

\section{Results}

Precipitation data collected at each site (Fig. 4) were not corrected for gauge undercatch, as corrections typically require local wind speed, which was not available for these sites. Monthly precipitation totals were calculated for both field sites and compared to PRISM estimates for each site (Fig. 5). PRISM estimates of monthly 


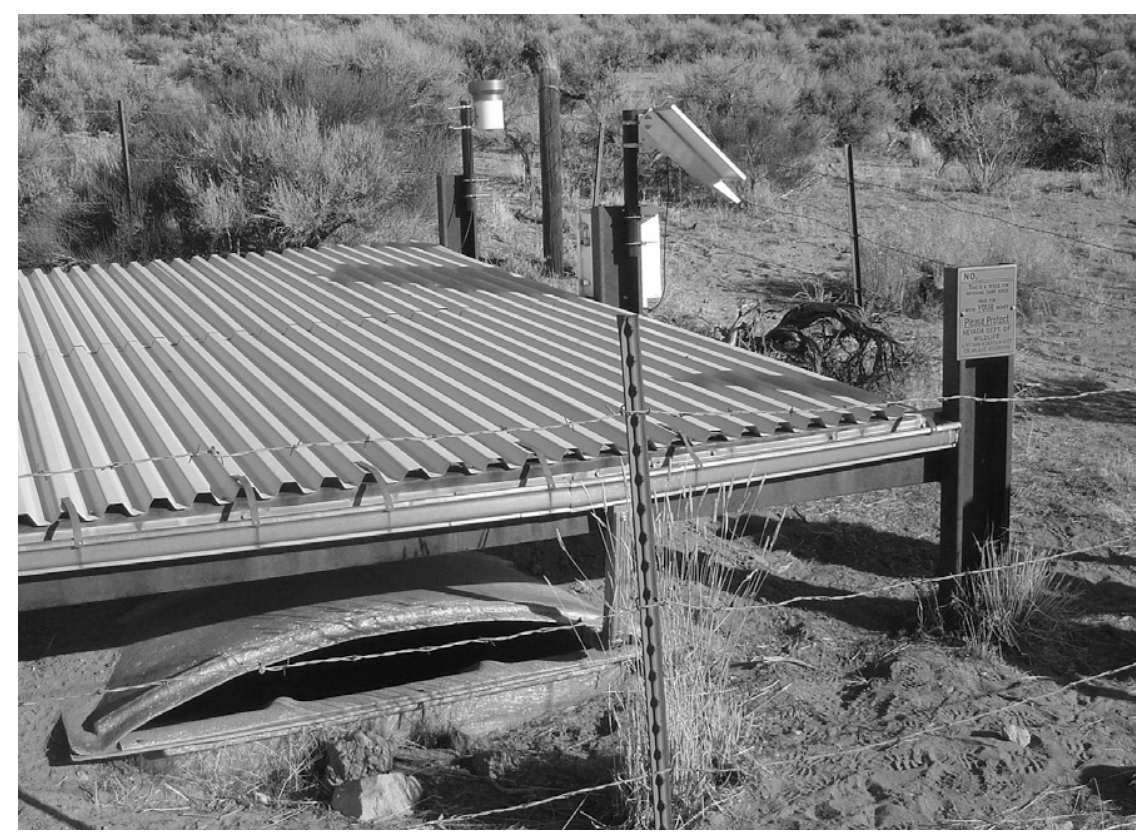

FIG. 3. Rain gauge, datalogger, and solar panel installation at Dry Valley No. 11 guzzler site.

precipitation and temperature are available in $4-\mathrm{km}$ (2.5 mi) grid cells (http://prism.oregonstate.edu). Both guzzler field sites fell close to the western border of their corresponding PRISM grid cells.

In addition, monthly maximum and minimum temperatures measured at the Dry Valley and Petersen sites were compared to PRISM estimates for monthly maximum and minimum temperatures (Fig. 6). Monthly temperature averages were calculated by determining daily maximum and minimum temperatures and averaging those values for each month. For the period of record, PRISM estimates of precipitation were approximately $1 \%$ lower than measured at the Dry Valley site and approximately $5 \%$ higher than measured at the Petersen site. Mean daily maximum and minimum measured temperatures at the Dry Valley site were, on average, $2.5^{\circ} \mathrm{C}$ higher and $0.7^{\circ} \mathrm{C}$ lower, respectively, than the PRISM estimate for each month of record. Mean daily maximum and minimum measured temperatures at the Petersen site averaged $4.2^{\circ} \mathrm{C}$ higher and $0.04^{\circ} \mathrm{C}$ lower, respectively, than the PRISM estimate for each month of record.

\section{Discussion and implications}

Cumulative precipitation, as measured by the TE gauge, and guzzler storage changes, as measured by the pressure transducer, followed each other well at both sites. For each increase in cumulative precipitation, there was a corresponding increase in water level in the cistern.
Measurements collected in the Petersen guzzler cistern exhibited abrupt increases in depth followed by equally abrupt decreases during winter months (Fig. 4). This can be attributed to the increases in pressure associated with water freezing around the transducer (Solinst 2009). These spikes do not correspond to precipitation events and would normally be removed in the data analysis process. They are displayed here to demonstrate the effectiveness of the balloon buffer system. Pressures increased during freezing conditions, but the highest pressures observed, corresponding to $0.8 \mathrm{~m}(2.6 \mathrm{ft})$ of water column depth, remained well below the $4 \mathrm{~m}$ (13.1 ft) that the Hobo U20-001-04 model transducer is designed to withstand.

Comparison of measured monthly precipitation values to estimated PRISM values at both sites returned interesting results. For the period of record at the Dry Valley site (35 months), although PRISM-estimated total precipitation was approximately $1 \%$ lower than the values measured at the guzzler, there were month-tomonth variations of up to $12 \mathrm{~mm}$ when comparing individual months to PRISM estimates (Fig. 5A). There were also month-to-month variations for the Petersen site, although it had only 26 months of record. Some of the differences between measured values and PRISM estimates could be due to undercatch by unshielded gauges; the use of tipping-bucket rain gauges, which may not adequately measure precipitation in freezing conditions; and the lack of nearby observations for the PRISM estimates. Because of the open landscape of 

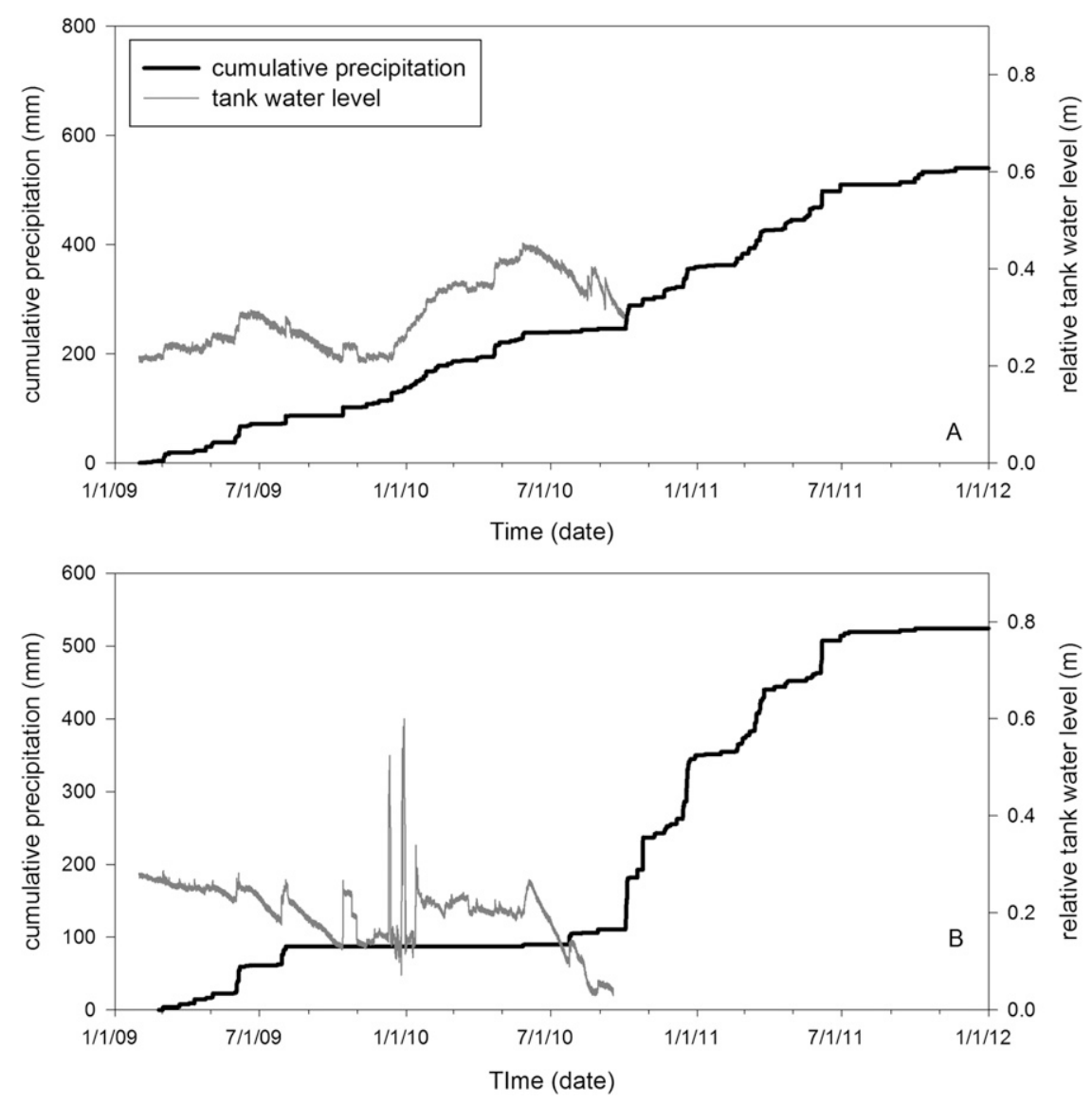

FIG. 4. Plots showing cumulative precipitation in relation to water levels in the guzzler cistern over time at (a) Dry Valley No. 11 and (b) Petersen No. 1 guzzler sites. Precipitation at Petersen No. 1 was not measured from 5 Aug 2009 to 12 May 2010 because of vandalism. Water levels in the cistern were not measured after 1 Oct 2010 and 17 Sep 2010 at the Dry Valley No. 11 and Petersen No. 1 guzzlers, respectively, because of the failure to reset the pressure transducers.

most Nevada guzzler sites, including the two sites we have instrumented, it is unlikely that nearby vegetation or obstacles affected gauge catch. The highest vegetation at most sites is no taller than the guzzler infrastructure and the gauge is mounted above it. However, such open conditions increase the likelihood of high wind speeds during storms, which can increase gauge undercatch of precipitation.

In addition, traditional methods of snow measurement presented a problem due to the scale, power requirements, and cost associated with these methods. To determine the timing of snowfall or the ratio of snow to rain at these sites, new instrumentation will need to be investigated, and perhaps developed to be a feasible option for prolonged remote deployment at guzzler field sites. Although the wildlife camera can be oriented to observe snow depth measurements, we have found that the camera does not function well at low temperatures and therefore may not reliably function when snow is present. We are currently experimenting with a sonar snow sensor that has been installed at each guzzler site to monitor snow depth. Unfortunately, the sensor was installed in fall 2011 but the winter of 2011/ 12 had very little snow precipitation at each site, so insufficient data were collected to evaluate the snow sensor performance.

Another source of the differences between measured and PRISM precipitation is that monthly PRISM estimates are based on stations with daily observation times that vary from station to station. This can result in precipitation occurring at the beginning and end of a month being attributed to adjacent months in different ways for different stations. When this occurs, a "seesaw" effect may be seen, where PRISM estimates for one month are too low and the next too high (or vice versa) compared to measurements at a particular site (for the guzzler measurements in this analysis, a day was defined as midnight to midnight local standard time). 


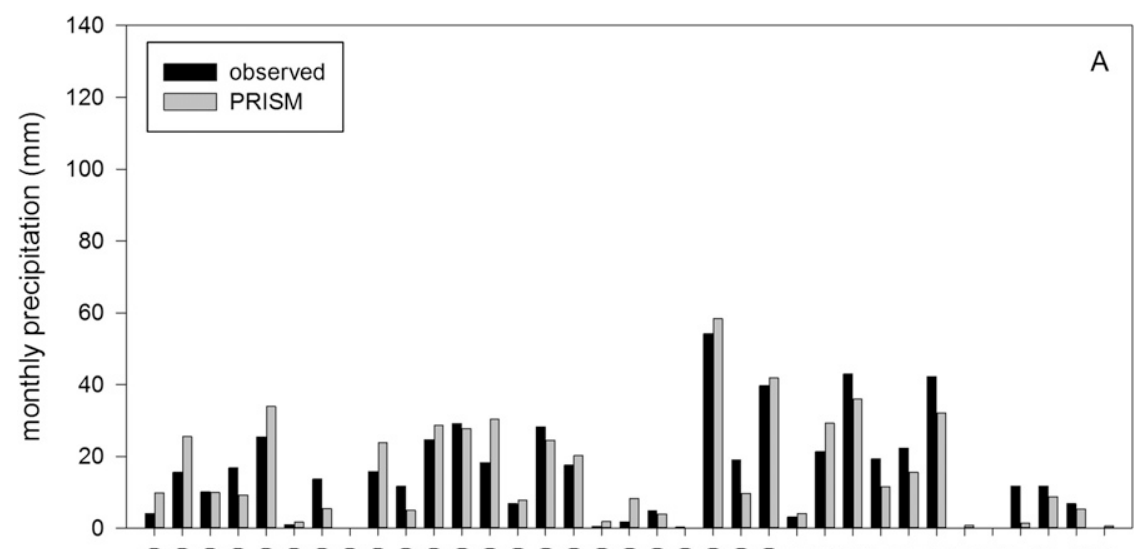

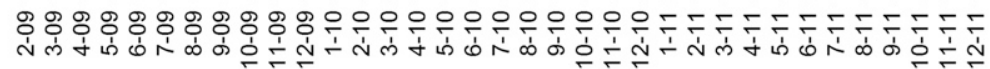

Time (date)

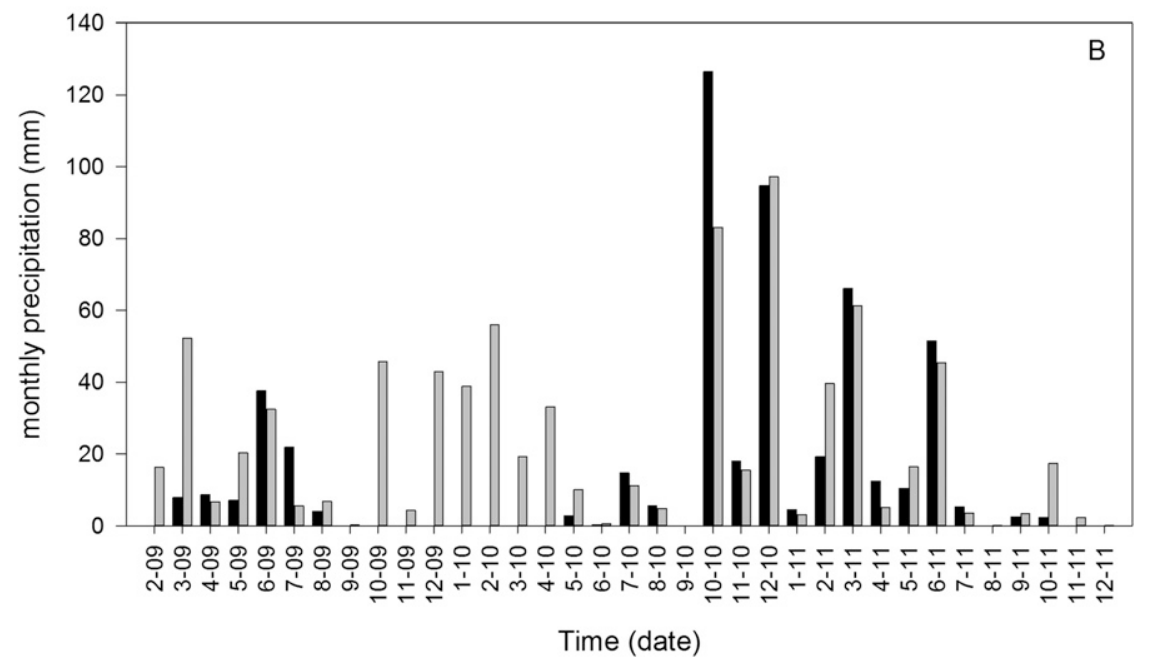

FIG. 5. Comparison of (a) Dry Valley No. 11 and (b) Petersen No. 1 monthly precipitation measurements to PRISM monthly precipitation estimates for February 2009-December 2011. Petersen observed data for February 2009 are for a partial month. Missing data at Petersen are due to vandalism.

PRISM estimates of monthly minimum air temperatures were very similar to those measured at each site, but site observations of maximum air temperatures were several degrees higher than PRISM estimates, except during the low-sun winter months. This was likely due to the temperature sensor being located inside the datalogger box, where ventilation is lacking. The sensor will be repositioned outside the box, and fitted with a Gillstyle radiation shield, which costs approximately $\$ 150$.

Unfortunately, we were unable to document wildlife visitation at the guzzler sites for the entire period of the study mainly due to vandalism, dead batteries, and malfunctioning cameras. Nonetheless, when the cameras were functioning properly, the guzzlers that were selected for instrumentation were frequently visited and used by wildlife. This documented visitation, along with water-level data collected from the cisterns, confirms that wildlife visiting these guzzlers would have water available to them for most of the year. Many of the photos of wildlife contained images of both adults and juveniles, suggesting that guzzlers may be an important source of water for wildlife raising young.

The results of our preliminary study are promising, and with additional research, guzzlers present a unique opportunity to add to available observational data in remote Nevada catchments in a cost-effective manner. They are typically installed in areas where data are lacking, and their design allows for easy installation of hydrometeorological instrumentation. Precipitation, air temperature, water storage, and runoff data can be collected at guzzler sites for less than $\$ 5000$ apiece (even with the addition of the radiation shield), much less than 


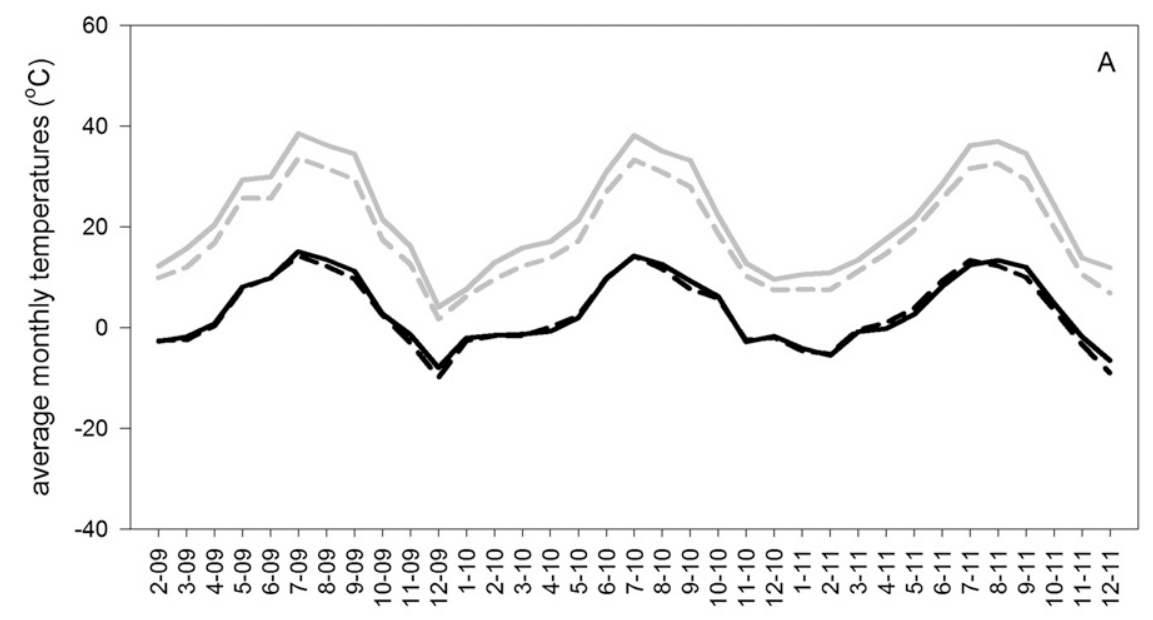

Time (date)

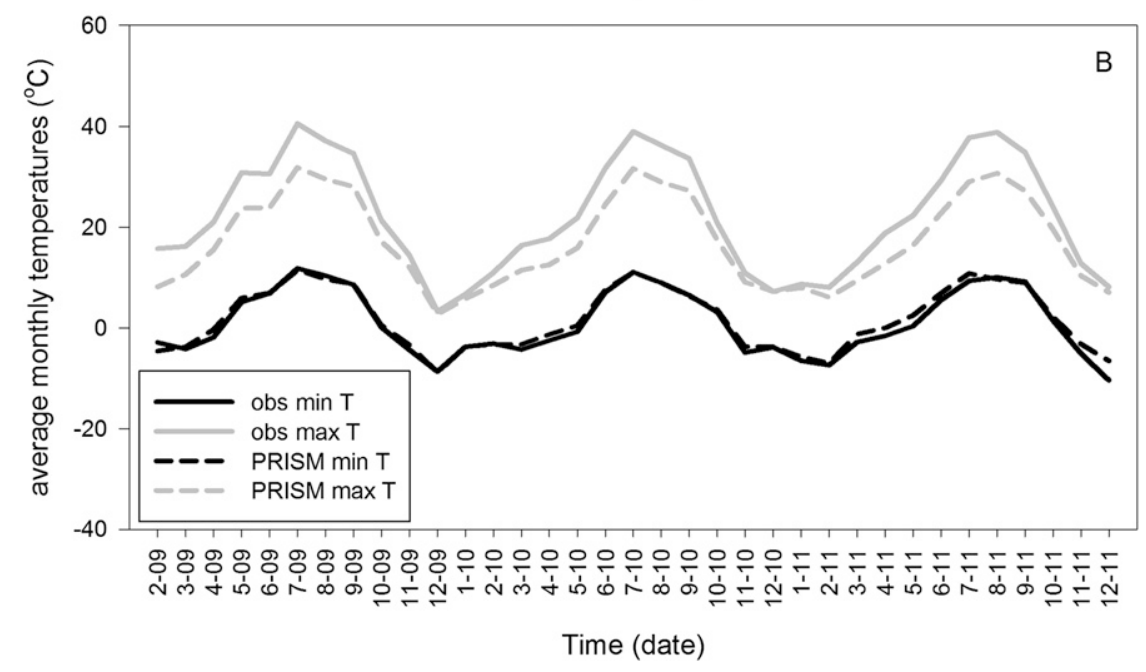

FIG. 6. Comparison of average measured monthly maximum and minimum temperatures vs the PRISM estimates for February 2009-December 2011 at (a) Dry Valley No. 11 and (b) Petersen No. 1 field sites. Petersen observed data for February 2009 are for a partial month.

a standard weather station ( $\$ 10,000$ or more). While periodic maintenance (e.g., replacing malfunctioning components) would bear additional cost, the low cost of the instrumentation and regular approximately annual maintenance schedule of the guzzlers would mean a relatively lower maintenance expense than equivalent maintenance on a standard automated station. Instrumenting guzzlers does include challenges, including data retrieval, instrument maintenance, and the chance of vandalism. Although this study demonstrates that guzzler sites can be augmented with climatic instrumentation at a relatively low cost and produce useful climate data, maximum temperature and winter precipitation measurements need to be improved before more guzzlers can be retrofitted with instrumentation. Further, observations from the retrofitted sites should be monitored and evaluated regarding whether improvements in spatial analyses are evident, which would benefit hydrologists, climatologists, and wildlife managers. With over 1600 guzzlers in Nevada, nearly 10 times the current number of COOP sites, and thousands more throughout the western United States, instrumented guzzlers have the potential for making significant improvements to spatial hydroclimatic analyses, such as those produced by PRISM.

Acknowledgments. Assistance with experimental trials, site instrumentation, and downloading was provided by Kate Grant, Rob Engel (UNR), and Mike Potts (UNR). Assistance in the site selection process was provided by John Gebhardt (NDOW) and Clint Garret (NDOW). Materials for runoff collectors and assistance with collector design were provided by Wally Miller (UNR). Contributions to project planning were made by Jeff 
Underwood (UNR) and Kelly Redmond (WRCC). GIS assistance was provided by Jasmine Vittori (UNR). The authors thank Louis Provencher and Craig Stevenson and three anonymous reviewers for providing helpful comments on the manuscript. USDA is an equal opportunity provider and employer. Research was funded in part by the Nevada Agricultural Experiment Station, the Bureau of Land Management, the United States Department of Agriculture/Agriculture Research Service, the Nevada Water Resources Association, and the University of Nevada/ Reno Academy for the Environment. Mention of a proprietary product does not constitute a guarantee or warranty of the product by USDA or the authors, and it does not imply its approval to the exclusion of the other products that also may be suitable.

\section{REFERENCES}

Bales, R. C., N. P. Molotch, T. H. Painter, M. D. Dettinger, R. Rice, and J. Dozier, 2006: Mountain hydrology of the western United States. Water Resour. Res., 42, W08432, doi:10.1029/ 2005 WR 004387.

Bleich, V. C., N. G. Andrew, M. J. Martin, G. P. Mulcahy, A. M. Pauli, and S. S. Rosenstock, 2006: Quality of water available to wildlife in desert environments: Comparisons among anthropogenic and natural sources. Wildl. Soc. Bull., 34, 627-632.

Daly, C., 2006: Guidelines for assessing the suitability of spatial climate data sets. Int. J. Climatol., 26, 707-721.

_ R. P. Neilson, and D. L. Phillips, 1994: A statistical-topographic model for mapping climatological precipitation over mountainous terrain. J. Appl. Meteor., 33, 140-158.

—, W. P. Gibson, G. H. Taylor, M. K. Doggett, and J. I. Smith, 2007: Observer bias in daily precipitation measurements at United States cooperative network stations. Bull. Amer. Meteor. Soc., 88, 899-912.

—, M. Halbleib, J. I. Smith, W. P. Gibson, M. K. Doggett, G. H. Taylor, J. Curtis, and P. A. Pasteris, 2008: Physiographicallysensitive mapping of temperature and precipitation across the conterminous United States. Int. J. Climatol., 28, 20312064.

Das, T., and Coauthors, 2009: Structure and detectability of trends in hydrological measures over the western United States. J. Hydrometeor., 10, 871-892.

Dingman, S. L., 2002: Physical Hydrology. 2nd ed. Prentice Hall, 600 pp.

Dolan, B. F., 2006: Wildlife use of water catchments in southwestern Arizona. Wildl. Soc. Bull., 34, 642-646.
Fiebrich, C. A., and K. C. Crawford, 2009: Automation: A step toward improving the quality of daily temperature data produced by climate observing networks. J. Atmos. Oceanic Technol., 26, 1246-1260.

Grant, N. J., 2010: Instrumenting wildlife water developments to collect hydrometeorological data in remote Nevada catchments. M.S. thesis, Graduate Program of Hydrologic Sciences, University of Nevada at Reno, $96 \mathrm{pp}$.

Groisman, P. Ya., and D. R. Legates, 1994: The accuracy of United States precipitation data. Bull. Amer. Meteor. Soc., 75, 215 227.

Habib, E. H., E. A. Meselhe, and A. V. Aduvala, 2008: Effect of local errors of tipping-bucket rain gauges on rainfall-runoff simulations. J. Hydrol. Eng., 13, 488-496.

Knowles, N., M. D. Dettinger, and D. R. Cayan, 2006: Trends in snowfall versus rainfall in the western United States. J. Climate, 19, 4545-4559.

Lynn, J. C., C. L. Chambers, and S. S. Rosenstock, 2006: Use of wildlife water developments by birds in southwest Arizona during migration. Wildl. Soc. Bull., 34, 592-601.

—, S. S. Rosenstock, and C. L. Chambers, 2008: Avian use of desert wildlife water developments as determined by remote videography. West. North Amer. Nat., 68, 107-112.

McCabe, G. J., M. P. Clark, and L. E. Hay, 2007: Rain-on-snow events in the western United States. Bull. Amer. Meteor. Soc., 88, 319-328.

NRCS, 2009a: SNOTEL and snow survey and water supply forecasting. Natural Resources Conservation Service Brochure, $2 \mathrm{pp}$.

_ 2009b: Soil Climate Analysis Network (SCAN). Natural Resources Conservation Service Brochure, 2 pp.

Nystuen, J. A., J. R. Proni, P. G. Black, and J. C. Wilkerson, 1996: A comparison of automatic rain gauges. J. Atmos. Oceanic Technol., 13, 62-73.

O'Brien, C. S., R. B. Waddell, S. S. Rosenstock, and M. J. Rabe, 2006: Wildlife use of water catchments in southwestern Arizona. Wildl. Soc. Bull., 34, 582-591.

Rosenstock, S., B. Ballard, and J. Devos Jr., 1999: Viewpoint: Benefits and impacts of wildlife water developments. J. Range Manage., 52, 302-311.

Sevruk, B., 1996: Adjustment of tipping-bucket precipitation gauge measurements. Atmos. Res., 42, 237-246.

Solinst, 2009: Levelogger user guide. Solinst Levelogger Series Software Version 4, 68 pp.

WRCC, cited 2011: Coop sites: Arizona. [Available online at http:// www.wrcc.dri.edu/summary/Climsmnv.html.]

Yang, D., B. E. Goodison, J. R. Metcalfe, V. S. Golubev, R. Bates, T. Pangburn, and C. L. Hanson, 1998: Accuracy of NWS 8" standard nonrecording precipitation gauge: Results and application of WMO intercomparison. J. Atmos. Oceanic Technol., 15, 54-68. 